\title{
Effect of Heating Time and Temperature on the Chemical Characteristics of Biochar from Poultry Manure
}

\author{
Giulia Cimò, ${ }^{\dagger}$ Jiri Kucerik, ${ }^{\S}$ Anne E. Berns, ${ }^{\#}$ Gabriele E. Schaumann, ${ }^{\S}$ Giuseppe Alonzo, ${ }^{\dagger}$ \\ and Pellegrino Conte* ${ }^{\dagger}$
}

\author{
${ }^{\dagger}$ Dipartimento di Scienze Agrarie e Forestali, Università degli Studi di Palermo, v.le delle Scienze edificio 4, 90128 Palermo, Italy \\ ${ }^{\S}$ Department of Environmental and Soil Chemistry, Institute for Environmental Sciences, University of Koblenz-Landau, Fortstrasse \\ 7, 76829 Landau, Germany \\ "Institute of Bio- and Geosciences, IBG 3: Agrosphere, Forschungszentrum Jülich GmbH, 52425 Jülich, Germany
}

ABSTRACT: Poultry manure (PM) chars were obtained at different temperatures and charring times. Chemical-physical characterization of the different PM chars was conducted by cross-polarization magic angle spinning (CPMAS) ${ }^{13} \mathrm{C}$ NMR spectroscopy and thermal analysis. CPMAS ${ }^{13} \mathrm{C}$ NMR spectra showed that the chemical composition of PM char is dependent on production temperature rather than on production duration. Aromatic and alkyl domains in the PM chars obtained at the lowest temperatures remained unchanged at all heating times applied for their production. The PM char obtained at the highest temperature consisted only of aromatic structures having chemical nature that also appeared invariant with heating time. Thermogravimetry revealed differences in the thermo-oxidative stability of the aromatic domains in the different PM chars. The PM char produced at the highest temperature appeared less stable than those produced at the lowest temperatures. This difference was explained by a protective effect of the alkyl groups, which are still present in chars formed at lower temperature. The analysis of the chemical and physicochemical character of poultry manure chars produced at different temperatures can increase understanding of the role of these materials in the properties and behavior of char-amended soils.

KEYWORDS: char, poultry manure, CPMAS ${ }^{13} \mathrm{C} N M R, T G A, D T G$, thermal stability

\section{INTRODUCTION}

Chicken or poultry manure (PM) consists of digested and transformed biomass along with the original litter material, feathers, and spilled feed that accumulate on the floors of the buildings where the animals are grown. ${ }^{1} \mathrm{PM}$ can be considered as a valuable source of readily available plant nutrients such as $\mathrm{N}, \mathrm{P}, \mathrm{K}$, and other micronutrients. ${ }^{2}$ For this reason $\mathrm{PM}$ is traditionally used by farmers as an effective organic fertilizer. ${ }^{3}$ Many studies in both temperate and tropical regions reported that large increases in soil organic matter content and fertility can be achieved by adding chicken manures and wastes to soils. $^{4-9}$ In particular, the use of poultry manure also contributes to raise soil $\mathrm{pH}$ with favorable effects on acidic soils. $^{10}$

Notwithstanding the advantages of PM for increasing soil fertility, there are food safety and environmental concerns about its application on agricultural sites in its unmodified form. $^{11,12}$ In fact, the misuse of chicken manure as fertilizer may result in serious environmental problems, ${ }^{13}$ such as human and animal health risks, odors, and leaching of nitrates and other pollutants into groundwater. ${ }^{14}$ For this reason, conversion of chicken manure to char has been proposed as an attractive methodology to reduce PM volume and weight and its odor. $^{15,16}$

Char is a fine-grained and highly porous carbonaceous material, arising from the pyrolytic decomposition of natural or synthetic organic materials. ${ }^{17}$ Due to its high carbon content and its high resistance to biological and chemical decomposition, many authors consider char applied to soils as a useful carbon sink for atmospheric $\mathrm{CO}_{2}$ sequestration, thereby contributing to the mitigation of global climate changes. ${ }^{18-21}$

Application of char to soils is nowadays controversial and still a matter of debate. In fact, on the one hand, significant agronomic benefits due to char application to soils have been reported. ${ }^{22-24}$ On the other hand, other studies reported not only insignificant effects of biochar on crop yields, but also some adverse dose-dependent peculiarities. ${ }^{25-28}$

The variability of char effects on soil properties may be due to the large variety of potential biophysical interactions and processes that occur when it is applied to soils. ${ }^{17,29}$

Char characteristics depend on the properties of the biomasses and the techniques applied for its production. ${ }^{17,22,30}$ Indeed, from the chemical point of view, all of the charred materials are recognized as polycondensed aromatic systems wherein the degree of polycondensation may differ according to the technique used for their production. ${ }^{31}$ As an example, lowtemperature-produced charred systems still contain plantgrowth-stimulating organic compounds. A low sorption capacity for cations has been observed for high-temperature chars, which can be improved by using even higher production temperatures. ${ }^{32}$ In addition, the polyaromatic macromolecular structure of charred biomasses is responsible for their chemical

Received: December 12, 2013

Revised: February 3, 2014

Accepted: February 7, 2014

Published: February 7, 2014 
Table 1. Elemental Content of Poultry Manure (PM) and PM Chars Obtained at 350, 450, and $600{ }^{\circ} \mathrm{C}$ for Heating Times of 30 , 60,90 , and $120 \min ^{a}$

\begin{tabular}{|c|c|c|c|c|c|}
\hline sample & heating time $(\mathrm{min})$ & C (\%) & $\mathrm{H}(\%)$ & $\mathrm{N}(\%)$ & $\mathrm{C} / \mathrm{H}$ \\
\hline poultry manure (PM) & & $30 \pm 2$ & $4 \pm 1$ & $2.6 \pm 0.3$ & $7 \pm 2$ \\
\hline \multirow[t]{4}{*}{$\mathrm{PM}$ char at $350^{\circ} \mathrm{C}$} & 30 & $32 \pm 2$ & $2.6 \pm 0.3$ & $2.1 \pm 0.1$ & $12 \pm 2$ \\
\hline & 60 & $34 \pm 1$ & $2.63 \pm 0.03$ & $2.4 \pm 0.3$ & $13.0 \pm 0.3$ \\
\hline & 90 & $30 \pm 2$ & $2.4 \pm 0.2$ & $2.1 \pm 0.2$ & $12 \pm 2$ \\
\hline & 120 & $31 \pm 2$ & $1.9 \pm 0.2$ & $2.3 \pm 0.3$ & $16 \pm 3$ \\
\hline \multirow[t]{4}{*}{$\mathrm{PM}$ char at $450^{\circ} \mathrm{C}$} & 30 & $27 \pm 2$ & $1.3 \pm 0.2$ & $1.62 \pm 0.08$ & $21 \pm 4$ \\
\hline & 60 & $30 \pm 1$ & $1.4 \pm 0.1$ & $1.75 \pm 0.06$ & $21 \pm 2$ \\
\hline & 90 & $29 \pm 1$ & $1.5 \pm 0.1$ & $1.88 \pm 0.02$ & $19 \pm 2$ \\
\hline & 120 & $24 \pm 1$ & $0.9 \pm 0.2$ & $1.5 \pm 0.2$ & $27 \pm 7$ \\
\hline \multirow[t]{4}{*}{$\mathrm{PM}$ char at $600^{\circ} \mathrm{C}$} & 30 & $26 \pm 7$ & $0.6 \pm 0.2$ & $1.2 \pm 0.4$ & $42 \pm 25$ \\
\hline & 60 & $24 \pm 2$ & $0.50 \pm 0.01$ & $1.08 \pm 0.04$ & $48 \pm 5$ \\
\hline & 90 & $24 \pm 1$ & $0.64 \pm 0.09$ & $1.23 \pm 0.02$ & $37 \pm 7$ \\
\hline & 120 & $25 \pm 3$ & $0.62 \pm 0.06$ & $1.24 \pm 0.09$ & $40 \pm 8$ \\
\hline
\end{tabular}

and microbial recalcitrance, which is also the cause of their long mean residence time in soils. ${ }^{33}$

The physical characteristics of the charred materials also depend on the nature of the biomasses subjected to the thermal stress. ${ }^{34,35}$ Indeed, plant species with many large-diameter cells in the stem tissues can lead to biochars containing larger amounts of macropores. ${ }^{31}$ Macropores in biochar applied to soils may enhance soil-draining properties and the capacity to retain larger molecules such as phenolic compounds. ${ }^{36}$

On this basis, we can infer that understanding the char chemical and physical properties is crucial to address its agronomical and environmental uses and allow meaningful preapplication quality assessments.

The aim of the present paper is to report on the changes occurring in the structure of poultry manure biochar when it is obtained at different temperatures and heating times. For this reason we applied cross-polarization magic angle spinning (CPMAS) ${ }^{13} \mathrm{C}$ NMR spectroscopy and thermogravimetric analysis (TGA). Results will show that production temperature is more important than heating time in the chemical-physical characteristics of PM biochar. Our findings appear to confirm recent data obtained on other different animal and vegetal biomasses. $^{35,37}$

\section{MATERIALS AND METHODS}

Sample Preparation. Poultry manure (PM) was collected from a Sicilian chicken farm, Conca d'Uovo, Misilmeri, Palermo, Italy $\left(38^{\circ} 3^{\prime} 4^{\prime \prime} \mathrm{N}, 13^{\circ} 25^{\prime} 32^{\prime \prime} \mathrm{E}\right)$. After sampling, the material was air-dried to a maximum moisture content of $20 \%$. The manure was then charred in $300 \mathrm{~mL}$ Pyrex flasks at atmospheric pressure by applying three temperatures: 350,450 , and $600^{\circ} \mathrm{C}$. At the beginning, residual air was still present in the system. Once the reaction started, oxygen was consumed and pyrolysis proceeded under anoxic conditions. The effectiveness of the pyrolysis was confirmed by the NMR analyses described below. For each temperature, heating times of 30, 60, 90, and 120 min were employed. PM chars were allowed to cool to room temperature after pyrolysis. They were then finely ground in a ceramic mortar and dried again at $105{ }^{\circ} \mathrm{C}$ overnight. The dried materials were stored in a desiccator until analyses.

Chemical Analyses of PM Chars. Elemental contents (C, H, N) for all samples were achieved by using a Vario MicroCUBE Elemental Analyzer (Elementar, Hanau, Germany). All of the results are reported in Table $1 . \mathrm{C}, \mathrm{H}$, and $\mathrm{N}$ values were not corrected for the ash and moisture contents.

CPMAS ${ }^{13} \mathrm{C}$ NMR Spectroscopy. A $7.05 \mathrm{~T}$ Varian UNITY INOVA (Varian Inc., Palo Alto, CA, USA), equipped with an Apex HX wide-bore probe operating at a ${ }^{13} \mathrm{C}$ frequency of $75.4 \mathrm{MHz}$, was used to acquire the ${ }^{13} \mathrm{C}$ NMR spectra. The samples were packed in $6 \mathrm{~mm}$ zirconium rotors with Teflon bottom and top spacers and Vespel drive tips. The temperature was kept constant at $25.0 \pm 0.1{ }^{\circ} \mathrm{C}$. Magic angle spinning was carried out at $8000 \pm 1 \mathrm{~Hz}$. A ${ }^{1} \mathrm{H} \mathrm{RF}$ field strength of $50.3 \mathrm{kHZ}$ and a ramp of $16 \mathrm{kHz}$ to account for inhomogeneity of the Hartmann-Hahn condition were applied. ${ }^{38}$ VNMRJ software (version 1.1 revision $\mathrm{D}$, Varian Inc.) was used to acquire all of the free induction decays (FID). Spectra were processed by Mestre-C software (version 4.9.9.9, Mestrelab Research, Santiago de Compostela, Spain). All of the FIDs were transformed by applying first a $2 \mathrm{~K}$ zero filling and then an exponential filter function with a line broadening (LB) of 50 Hz. Fully automatic baseline correction using a Bernstein algorithm was applied for baseline corrections.

Thermogravimetric Analyses. TGA was carried out using a Netzsch Simultaneous Thermal Analyzer STA 449 F3 Jupiter (Netzsch-Gerätebau GmbH, Selb, Germany). Alumina crucibles were used as sample holder. Prior to analyses, ground PM chars were equilibrated in a chamber with controlled humidity (relative humidity of $40 \%$ ). For the thermoanalytical experiments, the following conditions were applied: heating rate of $10{ }^{\circ} \mathrm{C} \mathrm{min}{ }^{-1}$ from 30 to $1000{ }^{\circ} \mathrm{C}$, under dynamic air atmosphere, flow rate of $50 \mathrm{~mL} \mathrm{~min}^{-1}$, and sample mass about $10 \mathrm{mg}$ (weighted with an accuracy of \pm 0.001 $\mathrm{mg}$ ). The measurements were repeated three times for each sample. Data were analyzed using the Netzsch Star software (NETZSCH Proteus software). The TG curves were derivated (DTG) to improve their resolution with respect to the number of degradation steps and their onsets. The first derivative of the TG trace represents the mass loss rate (expressed as $\% \mathrm{~min}^{-1}$ ) as a function of temperature. DTG curves are represented as a series of peaks, instead of an "integrate" stepwise curve (TG), in which the areas under the peaks are proportional to the total mass change of the sample. ${ }^{39}$ In this way, even subtle mass changes, not evident in the TG curves, can be highlighted by a DTG peak. ${ }^{39}$

\section{RESULTS AND DISCUSSION}

CPMAS ${ }^{13} \mathrm{C}$ NMR Investigations. Figure 1 shows the CPMAS ${ }^{13} \mathrm{C}$ NMR spectra of the PM and Figure 2 its char derivatives produced at 350,450 , and $600{ }^{\circ} \mathrm{C}$ for charring times of $30,60,90$, and $120 \mathrm{~min}$. 


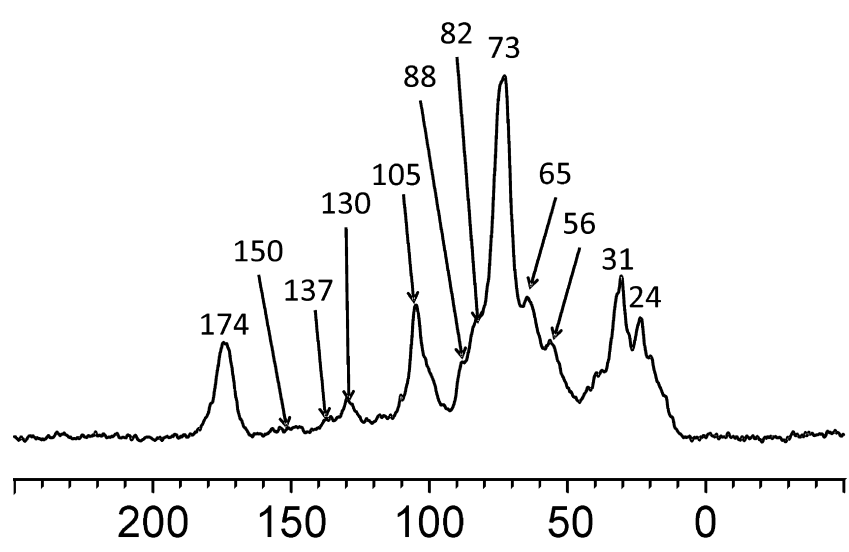

\section{Chemical shift (ppm)}

Figure 1. CPMAS ${ }^{13} \mathrm{C}$ NMR spectrum of the poultry manure.

The PM spectrum (Figure 1) reveals a signal pattern that is due to the typical plant material provided to chickens as food. In fact, signals in the region $0-50 \mathrm{ppm}$ are traditionally attributed to alkyl systems. Here, a predominance of methylene $\left(-\mathrm{CH}_{2}-\right)$ chains (peaks at 24 and $\left.31 \mathrm{ppm}\right)$ due to lipids, cutinlike structures, and other aliphatic biomolecules can be observed. $^{40,41}$

The region in the interval of 50-60 ppm is assigned to both nitrogenated and oxygenated alkyl systems. However, only a signal at $56 \mathrm{ppm}$ is visible. The latter is usually attributed to methoxyl groups in lignin-like structures. ${ }^{40,41}$

The NMR signal pattern between 60 and $110 \mathrm{ppm}$ is assigned to carbohydrates. Here, cellulose carbons resonate at 65 ppm (C-6), 73 ppm (C-2, C-3, C-5), 82 ppm (C-4 in amorphous cellulose, hemicellulose, and cellulose oligomers), and $88 \mathrm{ppm}$ (C-4 of cellulose on fibril surfaces). ${ }^{41}$ Finally, the anomeric carbon in cellulose appears at $105 \mathrm{ppm}^{40,41}$

The aromatic carbon spectral region is represented by the interval $110-160 \mathrm{ppm}$. The PM spectrum in Figure 1 reveals aromatic signals at 130,137, and $150 \mathrm{ppm}$. Due to the aforementioned signal at $56 \mathrm{ppm}$, aromatic signals are most likely assigned to lignin-like systems. ${ }^{41,42}$ In particular, the signal at $130 \mathrm{ppm}$ is generated by $p$-hydroxyphenol derivatives, whereas those at 137 and 150 are by syringyl-like systems. ${ }^{41}$

The last signal at $174 \mathrm{ppm}$ is assigned to carboxyl groups.

After pyrolysis at $350{ }^{\circ} \mathrm{C}$, the chemical composition of PM drastically changed (Figure $2 \mathrm{~A}$ ). In fact, regardless of the muffle residence time, only two sets of broad bands are observed in the alkyl (0-45 ppm) and aromatic (110-160 ppm) regions. In particular, three main signals can be recognized in the alkyl interval of the spectra, whereas the aromatic carbons produce only one broad signal centered at $130 \mathrm{ppm}$ (Figure 2A). The three main alkyl signals are placed at 14, 24, and $31 \mathrm{ppm}$. Whereas the latter two can be attributed to methylene chains as reported above, the former signal $(14 \mathrm{ppm})$ is generated by methyl groups terminating alkyl chains. The presence of large amounts of alkyl carbons in the $350{ }^{\circ} \mathrm{C}$ charred PM (Figure 2A) shows that the temperature of $350{ }^{\circ} \mathrm{C}$ is not sufficient to completely pyrolyze the poultry manure. In particular, aliphatic chains and carbohydrates are converted partly to polycyclic aromatic systems and partly to shorter alkyl moieties. These can either be immobilized to bridge aromatic moieties or be methyl-containing linear substituents on aromatic rings. ${ }^{17,31}$ At the longest residence time of $120 \mathrm{~min}$, the signal at $31 \mathrm{ppm}$, which stems from $-\mathrm{CH}_{2}-$ groups inside aliphatic chains, is noticeably reduced compared to the signals at 24 and $14 \mathrm{ppm}$. This indicates not only that the aliphatic content decreases with longer residence times but also that the chain length is reduced.

As reported in the literature, ${ }^{31}$ the amount of alkyl carbons decreases while that of the aromatic moieties increases, as

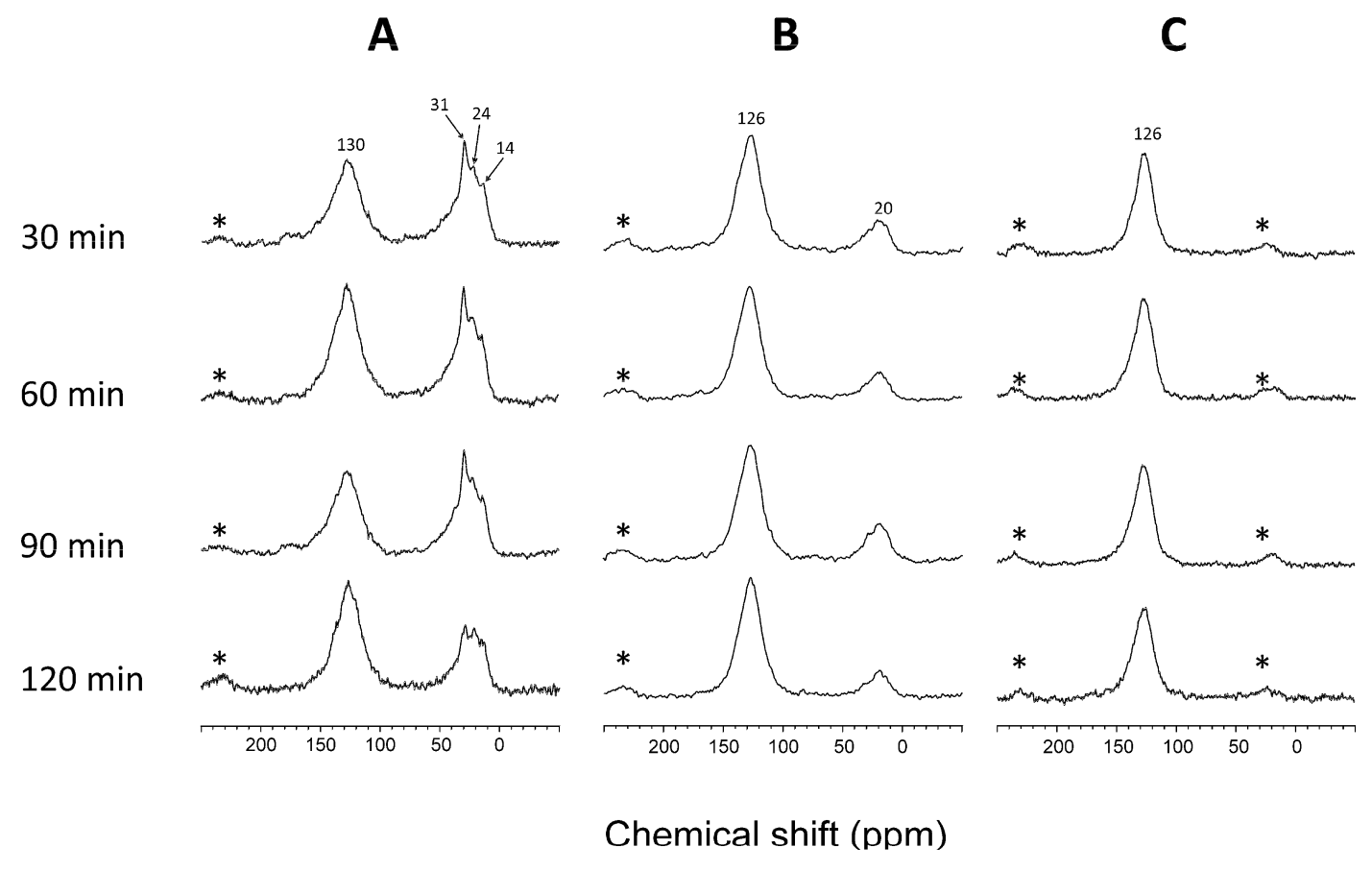

Figure 2. CPMAS ${ }^{13} \mathrm{C}$ NMR spectra of the poultry manure chars produced at $350{ }^{\circ} \mathrm{C}(\mathrm{A}), 450{ }^{\circ} \mathrm{C}(\mathrm{B})$, and $600{ }^{\circ} \mathrm{C}(\mathrm{C})$ for heating times of 30,60 , 90 , and $120 \mathrm{~min}$. The positions of spinning side bands (SSBs) are marked with asterisks (*). Note that the high-field SSB is overlapped by the alkyl resonances in the chemical shift interval $0-50 \mathrm{ppm}$. 

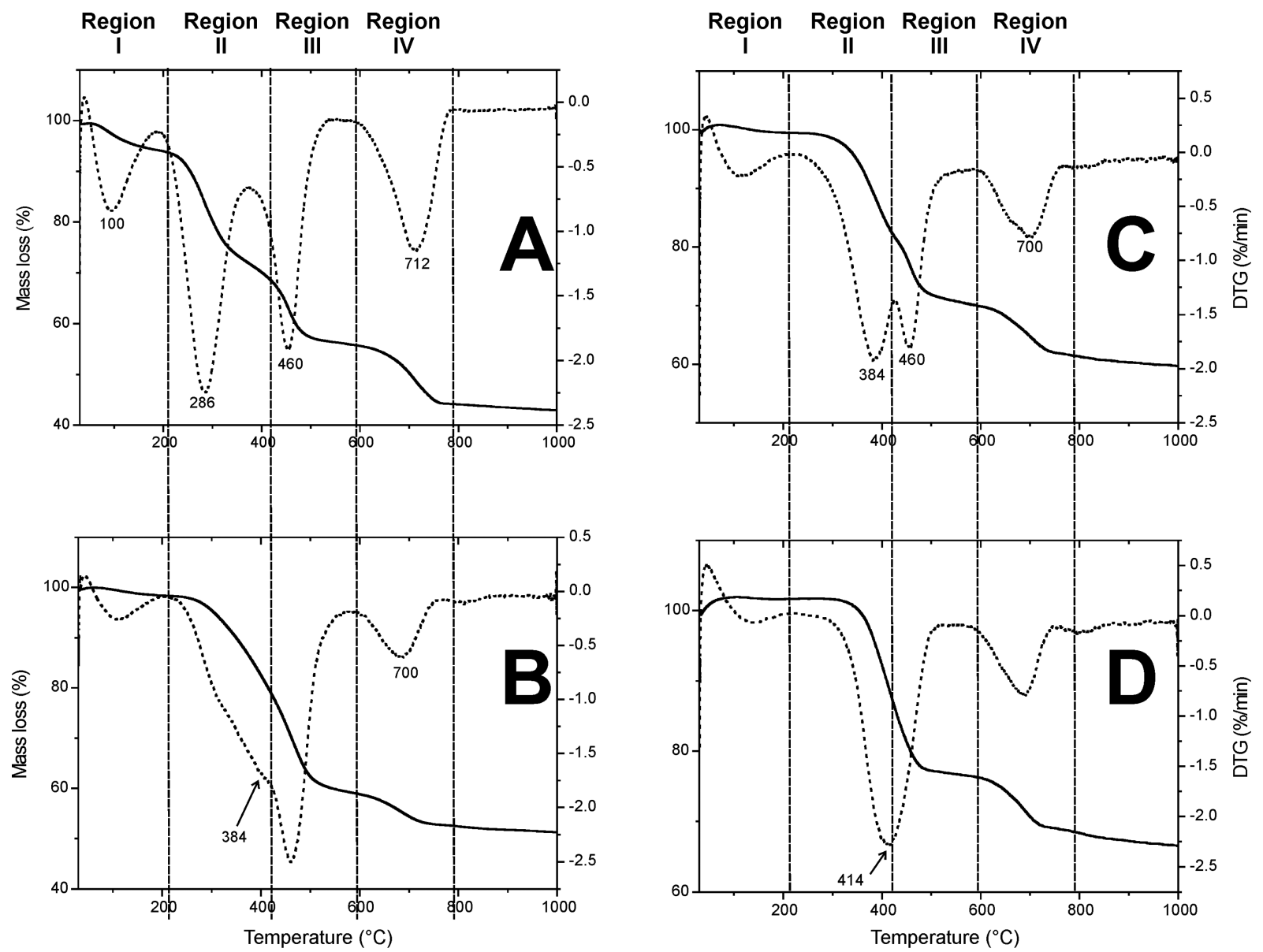

Figure 3. Thermograms (TG, solid lines) and first derivatives of the thermograms (DTG, dotted curves) for the poultry manure (A) and the chars obtained at $350{ }^{\circ} \mathrm{C}(\mathrm{B}), 450{ }^{\circ} \mathrm{C}(\mathrm{C})$, and $600{ }^{\circ} \mathrm{C}(\mathrm{D})$ and heating time of $120 \mathrm{~min}$. Four different regions can be identified. Region I refers to water removal, region II describes the mass loss due to thermal transformation of carbohydrates and alkyl labile systems, region III is associated with the thermal transformation of aromatic moieties; and region IV is due to transformation of the inorganic components of poultry manure chars.

charring temperature is raised. This is confirmed by the spectra of the poultry manure charred at 450 and $600{ }^{\circ} \mathrm{C}$ (Figure 2, panels $\mathrm{B}$ and $\mathrm{C}$, respectively). The pyrolysis at $450{ }^{\circ} \mathrm{C}$ at all muffle residence times produces charred materials containing mainly aromatic carbons (broad band at $126 \mathrm{ppm}$ in the spectra of Figure $2 \mathrm{~B}$ ). A strong reduction of the alkyl signal intensity is observed as compared to the spectra in Figure 2A. The comparison between the spectra in panels A and B of Figure 2 shows also a loss of resolution of the alkyl band in the spectrum of the biochar retrieved at $450{ }^{\circ} \mathrm{C}$. This finding can be explained by the reduction of the number of methyl-rich linear substituents and the formation of methyl-free alkyl bridges between aromatic rings.

The alkyl signal completely disappears after pyrolysis at 600 ${ }^{\circ} \mathrm{C}$ (Figure 2C), thereby supporting previous results showing that aromatic carbons are the main components in char systems when they are produced with temperatures above $500{ }^{\circ} \mathrm{C} . .^{17,35}$

It is worth noting that the NMR spectra of the chars obtained at each temperature were similar to each other regardless of the applied charring time (i.e., comparison of the spectra in Figure 2 from top to bottom along columns A, B, and C). However, a shift of $4 \mathrm{ppm}$ of the aromatic carbon chemical shift value can be observed when the spectra in Figure 2 are compared at the same charring time for the different temperatures. In fact, the aromatic carbons resonate at 130 $\mathrm{ppm}$ in the spectrum of the $\mathrm{PM}$ charred at $350{ }^{\circ} \mathrm{C}$, whereas they appear at $126 \mathrm{ppm}$ in the spectra of the PM chars obtained at 450 and $600{ }^{\circ} \mathrm{C}$. According to McBeath and Smernik, ${ }^{43}$ the higher the heating temperature applied for PM charring, the lower is the chemical shift value for the resonance of the aromatic carbons. This is due to the enhancement of the aromatic polycondensation degree as the charring temperature is raised. The elemental content reported in Table 1 further confirms the results from CPMAS ${ }^{13} \mathrm{C}$ NMR experiments. In fact, on the one hand, no changes are observed in the elemental compositions of the chars retrieved at the different heating times when pyrolysis is done at the three temperatures of 350 , 450 , and $600{ }^{\circ} \mathrm{C}$. This indicates that heating temperature is more important than heating time in affecting the chemical nature of PM chars, thereby confirming recent results by Wolf et $\mathrm{al}^{37}$ and Zhao et $\mathrm{al}^{35}$ on different char materials. On the other hand, the $\mathrm{C} / \mathrm{H}$ ratio increases with increasing charring temperature (Table 1 ). The larger the $\mathrm{C} / \mathrm{H}$ ratio, the higher the polycondensation degree of organic systems. This supports the conclusion that higher charring temperatures favor formation of polycondensed aromatic rings. 43

TGA. Figure 3 reports the thermogravimetic (TG) records (solid lines) of the poultry manure and its char products together with the first-derivative curve (DTG, dotted lines). The latter curve reflects the rate of the thermo-oxidative degradation. ${ }^{44}$ The chemical similarity among chars as evidenced by CPMAS ${ }^{13} \mathrm{C}$ NMR spectroscopy (see above) is 
also reflected in the TG/DTG curves reported in Figure 3. For this reason, only the TG/DTG profiles of the chars obtained at the heating time of $120 \mathrm{~min}$ are reported in Figure 3.

TG investigations revealed that mass loss (ML) was in the order $\mathrm{ML}_{600}{ }^{\circ} \mathrm{C}<\mathrm{ML}_{450{ }^{\circ} \mathrm{C}}<\mathrm{ML}_{350}{ }^{\circ} \mathrm{C} \approx \mathrm{ML}_{\mathrm{PM}}$ (Figure 3). This is expected because charring processes progressively reduce sample carbon, hydrogen, and nitrogen contents as heating temperature is increased. ${ }^{45,46}$ Table 1 supports the latter findings. In fact, the carbon amount varied from a mean value of $\approx 30 \%$ in the PM and PM chars obtained at $350{ }^{\circ} \mathrm{C}$ to an average of $\approx 28 \%$ in the $450{ }^{\circ} \mathrm{C} \mathrm{PM}$ chars and to an average of $\approx 25 \%$ in the chars retrieved at $600{ }^{\circ} \mathrm{C}$. Reduction of $\mathrm{H}$ and $\mathrm{N}$ contents followed the same trend. In fact, they were in the orders $\mathrm{H}_{\mathrm{PM}} \approx \mathrm{H}_{(\mathrm{PM} \text { chars at } 350)}>\mathrm{H}_{(\mathrm{PM} \text { chars at } 450)}>$ $\mathrm{H}_{\text {(PM chars at 600) }}$ and $\mathrm{N}_{\mathrm{PM}} \approx \mathrm{N}_{(\mathrm{PM} \text { chars at 350) }}>\mathrm{N}_{\text {(PM chars at 450) }}>$ $\mathrm{N}_{\text {(PM chars at } 600)}$, respectively.

Each TG/DTG curve has been operationally subdivided into four different mass loss steps at four specific temperature intervals (Figure 3). ${ }^{44,47}$ The first interval, in the temperature range $40-210^{\circ} \mathrm{C}$ (region I in Figure 3 ) with a progressive mass loss with the maximum rate around $100{ }^{\circ} \mathrm{C}$, is common for all samples. It refers to the loss of moisture adsorbed on PM and chars during the equilibration stage ( $\mathrm{RH} 40 \%)$ prior to analysis $^{44}$ (see Materials and Methods).

Region II spans a temperature interval from 210 to $420{ }^{\circ} \mathrm{C}$, whereas region III includes the interval $420-570^{\circ} \mathrm{C}$ (Figure 3 ). Poultry manure evidenced the maximum rate of the progressive mass loss at around $286{ }^{\circ} \mathrm{C}$ in region II. Conversely, the chars retrieved at 350 and $450{ }^{\circ} \mathrm{C}$ showed a maximum mass loss rate at around $384{ }^{\circ} \mathrm{C}$ in the same region. Moreover, both PM and PM chars produced at 350 and $450{ }^{\circ} \mathrm{C}$ revealed a maximum ML rate at around $460{ }^{\circ} \mathrm{C}$ in region III. Finally, the char sample retrieved at $600{ }^{\circ} \mathrm{C}$ showed only one DTG peak at around 414 ${ }^{\circ} \mathrm{C}$ placed between regions II and III (Figure 3). The last thermal region, IV, between 600 and $800{ }^{\circ} \mathrm{C}$ (Figure 3), with a DTG peak at around $700{ }^{\circ} \mathrm{C}$ in all of the samples, is attributed to the degradation of mineral and biogenic salts such as calcium and potassium carbonates usually present in poultry manure. ${ }^{47,48}$

Poultry manure has already been described as a complex mixture of alkyl moieties, sugars, aromatic systems, and acidic functions (see discussion above on CPMAS ${ }^{13} \mathrm{C} N M R$ spectroscopy). The TG/DTG curves reported in Figure 3A confirm those findings. In fact, region II in biomass thermograms is usually due to the thermo-oxidative degradation of labile alkyl systems, carbohydrates, and fatty acids. ${ }^{47,49}$ Conversely, region III is mainly assigned to mass loss of more recalcitrant aromatic moieties. ${ }^{47,49}$ The latter come from original structures and, partially, from structures that developed in previous stages during the degradation and recombination of aliphatic molecules. ${ }^{50}$ In particular, the highly oxygenated degree of the organic PM systems favors mass loss at the temperature of $286{ }^{\circ} \mathrm{C}$ in region II (Figure 3A). Conversely, the larger chemical stability of aromatic systems is responsible for the thermal degradation at the temperature of $460{ }^{\circ} \mathrm{C}$ as evidenced in region III (Figure 3A).

Following pyrolysis at 350 and $450{ }^{\circ} \mathrm{C}, \mathrm{PM}$ transforms into a char mainly made by alkyl and aromatic domains. All of the oxygenated functions are lost (see the CPMAS ${ }^{13} \mathrm{C}$ NMR spectroscopy discussion above). Alkyl systems are thermally more stable than the oxygen-rich moieties. For this reason, region II in Figure 3B,C reveals a mass loss at a temperature of
$384{ }^{\circ} \mathrm{C}$, which is around $100{ }^{\circ} \mathrm{C}$ higher than that observed in Figure 3A.

According to literature data, ${ }^{44,49,51}$ linkages of recalcitrant aromatic moieties disrupt between 430 and $600{ }^{\circ} \mathrm{C}$. This arises in region III at $460{ }^{\circ} \mathrm{C}$ in poultry manure (Figure $3 \mathrm{~A}$ ), and the chars retrieved at $350{ }^{\circ} \mathrm{C}$ (Figure 3B) and $450{ }^{\circ} \mathrm{C}$ (Figure 3C). Conversely, the aromatic systems of the chars obtained at 600 ${ }^{\circ} \mathrm{C}$ degraded at $414{ }^{\circ} \mathrm{C}$ (Figure 3D), which is a temperature 46 ${ }^{\circ} \mathrm{C}$ lower than that observed in Figure $3 \mathrm{~A}-\mathrm{C}$ and placed on the border of regions II and III.

To explain the thermo-oxidative instability of the aromatic domains of the $600{ }^{\circ} \mathrm{C} \mathrm{PM}$ chars as compared to the thermooxidative stability of the same domains in PM and PM chars at 350 and $450{ }^{\circ} \mathrm{C}$, differences in the conformational arrangements of the different molecular domains have been considered. ${ }^{52}$ In fact, it is conceivable that the nonaromatic domains in poultry manure and its 350 and $450{ }^{\circ} \mathrm{C}$ chars are mainly displaced on the surface of highly condensed or strongly associated polyaromatic systems. ${ }^{52}$ Due to this, the surficial nonaromatic components are degraded first during the TG investigation. The stable products obtained by this first degradation step ${ }^{50,53}$ protect the inner aromatic constituents toward the thermo-oxidative degradation, thereby decelerating the effective heat flow and preventing the char particles from penetration of reactive atmosphere. ${ }^{54}$ Conversely, the polyaromatic domain in the $600{ }^{\circ} \mathrm{C} \mathrm{PM}$ chars is degraded at a lower temperature $\left(\approx 400{ }^{\circ} \mathrm{C}\right.$ in Figure $\left.3 \mathrm{C}\right)$ than the other chars due to the absence of the protective effect of the nonaromatic components.

In conclusion, spectroscopic and thermal characterization of poultry manure and its char derivatives obtained at different temperatures and charring times revealed that char chemical nature is affected more by the former than by the latter. Although such a conclusion confirms findings from other authors, ${ }^{35}$ our study showed in addition an unexpected stability of the aromatic systems in the low-temperature-retrieved materials than in those obtained at the highest temperature. This result was explained by hypothesizing that the alkyl domains in chars produced at 350 and $450{ }^{\circ} \mathrm{C}$ were mainly displaced on the surface of a rigid aromatic core. For this reason, the thermal destruction of the original aromatic core was retrieved only after the complete degradation of the products developed from the original alkyl systems.

Alkyl removal by charring poultry manure at $600{ }^{\circ} \mathrm{C}$ left the aromatic domain unprotected, thereby allowing thermal degradation of the aromatic systems at a temperature lower than that measured for the $\mathrm{PM}$ chars produced at the two lowest temperatures $\left(350\right.$ and $\left.450{ }^{\circ} \mathrm{C}\right)$.

Due to the knowledge that conformation has on the sorption properties of chars (e.g., kinetics and thermodynamics of char sorption or residence time of adsorbed species), the understanding of the role of alkyl and aromatic domains in these interactions is of great importance.

\section{AUTHOR INFORMATION}

\section{Corresponding Author}

*(P.C.) E-mail: pellegrino.conte@unipa.it. Phone: 0039091 238 64673. Fax: 0039091484035.

\section{Funding}

This study was partially funded by Ateneo Italo-Tedesco/ Deutsch-Italienisches Hochschulzentrum through Vigoni project 2010. 


\section{Notes}

The authors declare no competing financial interest.

\section{ABBREVIATIONS USED}

PM, poultry manure; CPMAS, cross-polarization magic angle spinning; NMR, nuclear magnetic resonance; TGA, thermogravimetric analyses; DTG, derivative thermogravimetry; ML, mass loss

\section{REFERENCES}

(1) Roach, S.; Isenhart, L.; McKenna, L.; Cunningham, M. Filthy Feed - The Risky and Unregulated Practice of Feeding Poultry Litter to Cattle; FACT, Food Animal Concerns Trust: Chicago, IL, USA, 2009.

(2) Huang, G.; Wang, X.; Han, L. Rapid estimation of nutrients in chicken manure during plant-field composting using physicochemical properties. Bioresour. Technol. 2011, 102, 1455-1461.

(3) Chan, K. Y.; Van Zwieten, L.; Meszaros, I.; Downie, A.; Joseph, S. Using poultry litter biochars as soil amendments. Aust. J. Soil Res. 2008, 46, 437-444.

(4) Khaleel, R.; Reddy, K. P.; Overcash, M. R. Changes in soil physical properties due to waste applications: a review. J. Environ. Qual. 1981, 10, 133-141.

(5) Lal, R.; Kang, B. T. Management of organic matter in soils of the tropics and subtropics. XII Congress International Society Soil Science, New Delhi, India; CIRAD: Paris, France, 1982; pp 152-178.

(6) Metzger, L.; Yaron, B. Influence of sludge organic matter on soil physical properties. Adv. Soil Sci. 1987, 7, 141-163.

(7) Davies, D. B.; Payne, D. Management of soil physical properties. In Russell's Soil Conditions and Plant Growth, 11th ed.; Wild, A., Ed.; Longman: Harlow, Essex, UK, 1988.

(8) Sanchez, P. A.; Palm, C. A.; Szott, L. T.; Cuevas, E.; Lal, R. Organic input management in tropical agroecosystems. In Dynamics of Soil Organic Matter in Tropical Ecosystems; Coleman, D. C., Oades, J. M., Uehara, G., Eds.; University of Hawaii Press: Honolulu, HI, USA, 1989.

(9) Haynes, R. J.; Naidu, R. Influence of lime, fertilizer and manure applications on soil organic matter content and soil physical conditions: a review. Nutr. Cycl. Agroecosyst. 1998, 51 (2), 123-137.

(10) Perkins, H. F.; Parker, M. B.; Walker, M. L. Chicken Manure Its Production, Composition, and Use as a Fertilizer; Georgia Agricultural Experiment Stations Bulletin 123; 1964.

(11) Wilkinson, K. G.; Harapas, D.; Tee, E.; Tomkins, R. B.; Premier, R. Strategies for the Safe Use of Poultry Litter in Food Crop Production. Horticulture Australia Ltd.: Sidney, Australia, 2003.

(12) Chan, K. Y.; Van Zwieten, L.; Meszaros, I.; Downie, A.; Joseph, $\mathrm{S}$. Assessing the agronomic values of contrasting char materials on Australian hardsetting soil. In Proceedings of the Conference of the International Agrichar Initiative, April 30-May 2, 2007, Terrigal, NSW, Australia; 2007.

(13) Gay, S. W.; Schmidt, D. R.; Clanton, C. J.; Janni, K. A.; Jacobson, L. D.; Weisberg, S. Odor, total reduced sulfur and ammonia emissions from animal housing facilities and manure storage units in Minnesota. Appl. Eng. Agric. 2003, 19 (3), 347-360.

(14) Fan, Z. J.; Ai, Y. W.; Li, J. M.; Li, G. W. Discussion of controlling $\mathrm{N}$ loss from volatilization in animal manure. J. Sichuan Normal Univ. 2000, 23 (5), 548-550.

(15) Shinogi, Y.; Kanri, Y. Pyrolysis of plant, animal and human waste: physical and chemical characterization of the pyrolytic products. Bioresour. Technol. 2003, 90 (3), 241-247.

(16) Popov, V.; Itoh, H.; Brebbia, C. A.; Kungoles, A. Waste Management and the Environment II; WIT Press: Boston, MA, USA, 2004.

(17) De Pasquale, C.; Marsala, V.; Berns, A. E.; Valagussa, M.; Pozzi, A.; Alonzo, G.; Conte, P. Fast field cycling NMR relaxometry characterization of biochars obtained from an industrial thermochemical process. J. Soil Sediment 2012, 2, 1211-1221.
(18) Schmidt, M. W. I; Noack, A. G. Black carbon in soils and sediments: analysis, distribution, implications, and current challenges. Global Biogeochem. Cy. 2000, 14 (3), 777-793.

(19) Gaunt, J. L.; Lehmann, J. Energy balance and emissions associated with biochar sequestration and pyrolysis bioenergy production. Environ. Sci. Technol. 2008, 42, 4152-4158.

(20) Matthews, J. A. Carbon negative biofuels. Energy Policy 2008, 36, 940-945.

(21) Lehmann, J.; Czimczik, C.; Laird, D.; Sohi, S. Stability of biochar in the soil. In Biochar for Environmental Management: Science and Technology; Lehmann, J., Joseph, S., Eds.; Earthscan: London, UK, 2009.

(22) Sohi, S. P.; Krull, E.; Lopez-Capel, E.; Bol, R. A review of biochar and its use and function in soil. Adv. Agron. 2010, 105, 47-82.

(23) Uchimiya, M.; Lima, I. M.; Klasson, K. T.; Chang, S.; Wartelle, L. H.; Rodgers, J. E. Immobilization of heavy metal ions $\left(\mathrm{Cu}^{\mathrm{II}}, \mathrm{Cd}^{\mathrm{II}}\right.$, $\mathrm{Ni}^{\mathrm{II}}$, and $\left.\mathrm{Pb}^{\mathrm{II}}\right)$ by broiler litter-derived biochars in water and soil. $J$. Agric. Food Chem. 2010, 58, 5538-5544.

(24) Yuan, J. H.; Xu, R. K.; Wang, N.; Li, J. Y. Amendment of acid soils with crop residues and biochars. Pedosphere 2011, 21 (3), 302308.

(25) Kishimoto, S.; Sugiura, G. Charcoal as a soil conditioner. Int. Achieve Future 1985, 5, 12-23.

(26) Mikan, C. J.; Abrams, M. D. Altered forest composition and soil properties of historic charcoal hearths in southeastern Pennsylvania. Can. J. For. Res. 1995, 25, 687-696.

(27) Rondon, M. A.; Lehmann, J.; Ramirez, J.; Hurtado, M. Biological nitrogen fixation by common beans (Phaseolus vulgaris L.) increases with bio-char additions. Biol. Fert. Soils 2007, 43, 699-708.

(28) Rillig, M. C.; Wagner, M.; Salem, M.; Antunes, P. M.; George, C.; Ramke, H. G.; Titirici, M.-M.; Antonietti, M. Material derived from hydrothermal carbonization: effects on plant growth and arbuscular mycorrhiza. Appl. Soil Ecol. 2010, 45 (3), 238-242.

(29) Conte, P.; Marsala, V.; De Pasquale, C.; Bubici, S.; Valagussa, M.; Pozzi, A.; Alonzo, G. Nature of water-biochar interface interactions. GCB Bioenergy 2013, 5, 116-121.

(30) Krull, E. S.; Baldock, J. A.; Skjemstad, J. O.; Smernik, R. J. Characteristics of biochar: organo-chemical properties. In Biochar for Environmental Management: Science and Technology; Lehmann, J., Joseph, S., Eds.; Earthscan: London, UK, 2009.

(31) Lehmann, J.; Joseph, S. Biochar for environmental management: an introduction. In Biochar for Environmental Management: Science and Technology; Lehmann, J., Joseph, S., Eds.; Earthscan: London, UK, 2009.

(32) Gundale, M. J.; De Luca, T. H. Temperature and source material influence ecological attributes of ponderosa pine and Douglasfir charcoal. For. Ecol. Manag. 2006, 231, 86-93.

(33) Knicker, H. Pyrogenic organic matter in soil: its origin and occurrence, its chemistry and survival in soil environments. Quat. Int. 2011, 243 (2), 251-263.

(34) Wiedner, K.; Rumpel, C.; Steiner, C.; Pozzi, A.; Maas, R.; Glaser, B. Chemical evaluation of chars produced by thermochemical conversion (gasification, pyrolysis and hydrothermal carbonization) of agro-industrial biomass on a commercial scale. Biomass Bioenergy 2013, DOI: $10.1016 /$ j.biombioe.2013.08.026 (article in press).

(35) Zhao, L.; Cao, X.; Mašek, O.; Zimmerman, A. Heterogeneity of biochar properties as a function of feedstock sources and production temperatures. J. Hazard Mater. 2013, 256-257, 1-9.

(36) Warnock, D. D.; Lehmann, J.; Kuyper, T. W.; Rilling, M. C. Mycorrhizal responses to biochar in soil - concepts and mechanisms. Plant Soil 2007, 300, 9-20.

(37) Wolf, M.; Lehndorff, E.; Wiesemberg, G. L. B.; Stockhausen, M.; Schwark, L.; Amelung, W. Towards reconstruction of past fire regimes from geochemical analysis of charcoal. Org. Geochem. 2013, 55, 11-21.

(38) Berns, A. E.; Conte, P. Effect of ramp size and sample spinning speed on CPMAS C-13 NMR spectra of soil organic matter. Org. Geochem. 2011, 42, 926-935.

(39) Wendlandt, W. W. M. Thermal Analysis; Wiley: New York, 1986. 
(40) Gómez, X.; Diaz, M. C.; Cooper, M.; Blanco, D.; Morán, A.; Snape, C. E. Study of biological stabilization processes of cattle and poultry manure by thermogravimetric analysis and ${ }^{13} \mathrm{C}$ NMR. Chemosphere 2007, 68, 1889-1897.

(41) Conte, P.; De Pasquale, C.; Novotny, E. H.; Caponetto, G.; Laudicina, V. A.; Ciofalo, M.; Panno, M.; Palazzolo, E.; Badalucco, L.; Alonzo, G. CPMAS ${ }^{13} \mathrm{C}$ NMR characterization of leaves and litters from the reafforestated area of Mustigarufi in Sicily (Italy). Open Magn. Reson. J. 2010, 3, 89-95.

(42) Wilson, M. A. N.M.R. Techniques and Applications in Geochemistry and Soil Chemistry, 1st ed.; Pergamon Press: London, UK, 1987.

(43) McBeath, A. V.; Smernik, R. J. Variation in the degree of aromatic condensation of chars. Org. Geochem. 2009, 40, 1161-1168.

(44) Kucerik, J.; Kovar, J.; Pekar, M. Thermoanalytical investigations of lignite humic acid fractions. J. Therm. Anal. Calorim. 2004, 76, 5565.

(45) Alèn, R.; Kuoppala, E.; Oesch, P. Formation of the main degradation compound groups from wood and its components during pyrolysis. J. Anal. Appl. Pyrolysis 1996, 36, 137-148.

(46) Gaskin, J. W.; Steiner, C.; Harris, K.; Das, K. C.; Bibens, B. Effect of low-temperature pyrolysis conditions on biochar for agricultural use. Trans. ASAE 2008, 51, 2061-2069.

(47) Dell'Abate, M. T.; Benedetti, A.; Sequi, P. Thermal methods of organic matter maturation monitoring during a composting process. $J$. Therm. Anal. Calorim. 2000, 61 (2), 389-396.

(48) Liodakis, S.; Katsigiannis, G.; Kakali, G. Ash properties of some dominant Greek forest species. Thermochim. Acta 2005, 437, 158-167.

(49) Lopez-Capel, E.; Sohi, S. P.; Gaunt, J. L.; Manning, D. A. C. Use of thermogravimetry-differential scanning calorimetry to characterize modelable soil organic matter fractions. Soil Sci. Soc. Am. J. 2005, 69, $136-140$.

(50) Kucerik, J.; Kamenarova, D.; Valkova, D.; Pekar, M.; Kislinger, J. The role of various compounds in humic acids stability studied by TG and DTA. J. Therm. Anal. Calorim. 2006, 84 (3), 715-720.

(51) Melligan, F.; Dussan, K.; Auccaise, R.; Novotny, E. H.; Leahy, J. J.; Hayes, M. H. B.; Kwapinski, W. Characterization of the products from pyrolysis of residues after acid hydrolysis of Miscanthus. Bioresour. Technol. 2012, 108, 258-263.

(52) Conte, P.; Berns, A. E. Dynamics of cross polarization in solid state nuclear magnetic resonance experiments of amorphous and heterogeneous natural organic substances. Anal. Sci. 2008, 24 (9), $1183-1188$.

(53) Valkova, D.; Kislinger, J.; Pekar, M.; Kucerik, J. The kinetics of thermo-oxidative humic acids degradation studied by isoconversional methods. J. Therm. Anal. Calorim. 2007, 89 (3), 957-964.

(54) Šesták, J. Heat, Thermal Analysis and Society; Nucleus HK Press: Hradec Kralove, Czech Republic, 2004. 